\title{
Adolescents and primary care
}

\author{
Marina Picca*, Roberto Marinello \\ From 71st Congress of the Italian Society of Pediatrics. Joint National Meeting SIP, SIMGePeD, Study Group \\ on Pediatric Ultrasound, SUP Study Group on Hypertension \\ Rome, Italy. 4-6 June 2015
}

From 1978 National Health System (NHS) primary care pediatricians (PdF) in Italy take care of infants and adolescents from birth until 14 (in selected cases 16) years of age [1]. They are not allowed to take care of their patients up to 18 years, so it's not possible to follow the whole adolescence under the NHS. There is also increased awareness in families that the pediatrician is the natural medical reference of a teenager; their education and training allows the understanding of changes due to puberty and their experience and background permit thorough understanding not only of the physical but also of the psychological and social changes which belong to this period of transition [2]. However, pediatricians are increasing their knowledge and competence regarding adolescent care and are promoting new preventive programs for adolescent health, such as the "Adolescents Health Project" to strengthen the preventative and educative actions and improve the lifestyle of the young.

Another objective of primary care pediatricians will be to structure shared programs with general practitioners (MMG) to favour the shift of care from the primary care pediatrician to the family doctor. It should be necessary to always support a well planned care transition between Pdf and MMG (exchange of computerized or paper medical records and when possible direct contact). This will enable the MMG to receive the complete information on the health of the patient as well as on social and relational aspects.

Published: 30 September 2015

\section{References}

1. Accordo Collettivo Nazionale (A.C.N.). 2005.

2. Hardoff D, Halevy H, Knishkowy B: The physician's role in adolescents' health education. It Journ Pediatr 2003, 29:398-403.

\footnotetext{
* Correspondence: piccamarina@gmail.com
} SICuPP, Milan, Italy

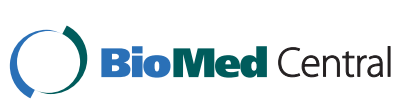

(c) 2015 Picca and Marinello. This is an Open Access article distributed under the terms of the Creative Commons Attribution License (http://creativecommons.org/licenses/by/4.0), which permits unrestricted use, distribution, and reproduction in any medium, provided the original work is properly cited. The Creative Commons Public Domain Dedication waiver (http://creativecommons.org/ publicdomain/zero/1.0/) applies to the data made available in this article, unless otherwise stated. and take full advantage of:

- Convenient online submission

- Thorough peer review

- No space constraints or color figure charges

- Immediate publication on acceptance

- Inclusion in PubMed, CAS, Scopus and Google Scholar

- Research which is freely available for redistribution

Submit your manuscript at Submit your manuscript at
www.biomedcentral.com/submit C BioMed Central 